\title{
Specific Loss of Brain ABCA1 Increases Brain Cholesterol Uptake and Influences Neuronal Structure and Function
}

\author{
Joanna M. Karasinska, ${ }^{1}$ Franz Rinninger, ${ }^{2}$ Dieter Lütjohann, ${ }^{3}$ Piers Ruddle, ${ }^{1}$ Sonia Franciosi, ${ }^{1}$ Janine K. Kruit, ${ }^{1}$ \\ Roshni R. Singaraja, ${ }^{1}$ Veronica Hirsch-Reinshagen, ${ }^{1}$ Jianjia Fan, ${ }^{1}$ Liam R. Brunham, ${ }^{1}$ Nagat Bissada, ${ }^{1}$ \\ Rajasekhar Ramakrishnan, ${ }^{4}$ Cheryl L. Wellington, ${ }^{1}$ John S. Parks, ${ }^{5}$ and Michael R. Hayden ${ }^{1}$ \\ ${ }^{1}$ Centre for Molecular Medicine and Therapeutics, University of British Columbia, Vancouver, British Columbia, V5Z 4H4 Canada, ${ }^{2}$ University Hospital \\ Hamburg Eppendorf, 20246 Hamburg, Germany, ${ }^{3}$ Institute of Clinical Chemistry and Pharmacology, University of Bonn, 53127 Bonn, Germany, ${ }^{4}$ Division \\ of Biostatistics, Columbia University College of Physicians and Surgeons, New York, New York 10032, and 5 Department of Pathology, Section on Lipid \\ Sciences, Wake Forest University School of Medicine, Winston-Salem, North Carolina 27157
}

The expression of the cholesterol transporter ATP-binding cassette transporter A1 (ABCA1) in the brain and its role in the lipidation of apolipoproteins indicate that ABCA1 may play a critical role in brain cholesterol metabolism. To investigate the role of ABCA1 in brain cholesterol homeostasis and trafficking, we characterized mice that specifically lacked ABCA1 in the CNS, generated using the Cre/loxP recombination system. These mice showed reduced plasma high-density lipoprotein (HDL) cholesterol levels associated with decreased brain cholesterol content and enhanced brain uptake of esterified cholesterol from plasma HDL. Increased levels of HDL receptor SR-BI in brain capillaries and apolipoprotein A-I in brain and CSF of mutant mice were evident. Cholesterol homeostasis changes were mirrored by disturbances in motor activity and sensorimotor function. Changes in synaptic ultrastructure including reduced synapse and synaptic vesicle numbers were observed. These data show that $\mathrm{ABCA1}$ is a key regulator of brain cholesterol metabolism and that disturbances in cholesterol transport in the CNS are associated with structural and functional deficits in neurons. Moreover, our findings also demonstrate that specific changes in brain cholesterol metabolism can lead to alterations in cholesterol uptake from plasma to brain.

\section{Introduction}

Cholesterol is required for myelination (Saher et al., 2005), dendrite differentiation (Goritz et al., 2005) and synaptic activity (Mauch et al., 2001). Disturbances in CNS cholesterol homeostasis are implicated in neurodegenerative diseases including Alzheimer's (Vance et al., 2005) and Huntington disease (Valenza et al., 2005).

Normally, plasma cholesterol is not taken up by the brain because of the tight junctions between brain capillary endothelial cells (BCECs) (Björkhem and Meaney, 2004; Dietschy and Turley, 2004). Brain cholesterol is synthesized in situ, and excretion of excess cholesterol occurs primarily after conversion to $24 \mathrm{~S}-\mathrm{OH}$ cholesterol by the brain-specific enzyme CYP46A1 (Dietschy and Turley, 2004). CNS cholesterol biosynthesis is high during development but declines after myelination is complete (Quan et al., 2003). It is postulated that adult neurons depend on glia-secreted cholesterol transported on apolipoprotein E (ApoE)-containing

Received 0ct. 2, 2008; revised Dec. 5, 2008; accepted Jan. 15, 2009.

This work was supported by the Canadian Institutes of Health Research (M.R.H.) and National Institutes of Health Grant HL 49373 (J.S.P.). J.M.K. holds postdoctoral fellowships from the Heart and Stroke Foundation of Canada and the Michael Smith Foundation for Health Research. M.R.H. holds a Canada Research Chair in Human Genetics. We thank Silvia Friedrichs, Anja Kerksiek for technical assistance, Rochelle Hines for advice with the electron microscopy experiment, and Dr. David Russell for the CYP46A1 antibody.

Correspondence should be addressed to Michael R. Hayden, Centre for Molecular Medicine and Therapeutics, University of British Columbia, 950 West 28th Ave, Room 3026, Vancouver, B.C., V5Z 4H4 Canada. E-mail: mrh@cmmt.ubc.ca.

DOI:10.1523/JNEUROSCI.4741-08.2009

Copyright $\odot 2009$ Society for Neuroscience $\quad$ 0270-6474/09/293579-11\$15.00/0
HDL-like particles (Mauch et al., 2001) and taken up by neurons via ApoE receptors (Vance et al., 2005).

ATP-binding cassette transporter A1 (ABCA1) mediates the transport of intracellular cholesterol to extracellular lipidfree apolipoprotein A-I (ApoA-I) and ApoE (Oram and Heinecke, 2005), a process critical for HDL synthesis (BrooksWilson et al., 1999). ABCA1 is expressed in neurons and glia (Wellington et al., 2002; Hirsch-Reinshagen et al., 2004; Tachikawa et al., 2005). The most important apolipoproteins in brain lipid homeostasis are ApoE, synthesized and secreted by astrocytes, and ApoA-I, derived from plasma or BCECs (Pitas et al., 1987; Weiler-Güttler et al., 1990). ABCA1 mediates cholesterol transport from glia to ApoE and ApoA-I and is critical for efficient secretion and lipidation of brain ApoE (Hirsch-Reinshagen et al., 2004; Wahrle et al., 2004). Despite the role of CNS cholesterol in synaptic function and neurodegenerative disorders, mechanisms regulating its transport and homeostasis are not well understood. Moreover, not much is known about how specific changes in CNS lipid metabolism impact plasma cholesterol.

In mice lacking ABCA1 globally, the specific role of brain ABCA1 cannot be studied without concurrent changes in whole body cholesterol homeostasis. Abcal ${ }^{-1-}$ mice have very low plasma HDL and ApoA-I (Oram and Heinecke, 2005) diminishing the pool of ApoA-I available for transport into the CNS and lack ABCA1 in BCECs, each of which can have separate effects on CNS cholesterol homeostasis. Indeed, previous studies of specific deletion of ABCA1 in pancreas (Brunham et al., 2007) and intes- 
tine (Brunham et al., 2006) have unmasked tissue specific functions of ABCA1 not readily apparent in $\mathrm{Abcal}^{-1-}$ mice.

To examine the exclusive role of brain ABCA1 in CNS cholesterol homeostasis and behavioral function, we developed mice lacking ABCA1 in neurons and glia $\left(A b c a 1^{-B /-B}\right)$. These mice exhibit reduced plasma HDL cholesterol levels and increased brain uptake of esterified cholesterol from plasma HDL. Locomotor activity and sensorimotor function are altered in $A b c a 1^{-B /-B}$ mice and the number of cortical excitatory synapses and synaptic vesicles are decreased.

These findings demonstrate that ABCA1 plays a critical role in brain cholesterol homeostasis and regulates behavioral function and synaptic development. Our results also show that perturbed brain cholesterol balance can alter the uptake of cholesterol from plasma to brain.

\section{Materials and Methods}

Animals. Mice lacking ABCA1 selectively in the brain were generated by crossing ABCA1 floxed mice (Timmins et al., 2005) with nestin-Cre mice (Jackson ImmunoResearch Laboratories). ABCA1 floxed (control mice) and ABCA1 floxed, nestin-Cre positive $\left(A b c a 1^{-B /-B}\right)$ littermates at 3 months of age were used in the experiments unless stated otherwise. Mice were housed under $12 \mathrm{~h}$ light/dark cycles and received a standard laboratory chow diet. All animal procedures were approved by the University of British Columbia Animal Care Committee.

Brain and plasma sterol analysis. Mice were killed by anesthetic overdose, blood was collected and cortex and hippocampus were dissected. Sterols were extracted from brain tissues as well as plasma using chloroform-methanol. The levels of each sterol were determined after conversion to the corresponding trimethylsilyl ethers by gas chromatography-flame ionization detection and gas chromatographymass spectrometry as reported previously (Lütjohann et al., 2002). Tissue dry weight was determined after overnight drying in a SpeedVac ultracentrifuge dryer (ThermoFisher Scientific). Plasma cholesterol, HDLcholesterol, phospholipids and triglycerides were measured by standard enzymatic assays (Wako Pure Chemical Industries).

Brain HDL and cholesteryl ester uptake. Analysis of HDL metabolism was performed as previously described (Pittman and Taylor, 1986). HDL (density $=1.063-1.21 \mathrm{~g} / \mathrm{ml}$ ) was isolated from wild-type C57BL/6J mice by centrifugation and labeled with ${ }^{125} \mathrm{I}$-tyramine cellobiose $\left({ }^{125} \mathrm{I}-\right.$ TC) in its protein and ${ }^{3} \mathrm{H}$-cholesteryl oleyl ether $\left({ }^{3} \mathrm{H}-\mathrm{CEt}\right)$ (GE Healthcare Bio-Sciences) in its cholesteryl ester (CE) moiety. Mice were injected with ${ }^{125} \mathrm{I}$-TC- and ${ }^{3} \mathrm{H}$-CEt double-labeled HDL via the tail vein, blood samples were collected at different time points and plasma decay rates (fractional catabolic rate, FCR) for ${ }^{125} \mathrm{I}$ and ${ }^{3} \mathrm{H}$ were calculated. Mice were killed $24 \mathrm{~h}$ after injection and brain levels of HDL-associated ${ }^{125} \mathrm{I}-\mathrm{TC}$ as well as ${ }^{3} \mathrm{H}$-CEt were determined. Brain uptake rates of ${ }^{125} \mathrm{I}-\mathrm{TC}$ and ${ }^{3} \mathrm{H}$-CEt are expressed as organ FCR and are calculated as follows: Brain FCR $=$ plasma FCR $\times$ fraction of total body tracer recovered in brain (Pittman and Taylor, 1986).

Selective HDL-CE uptake is calculated as the difference in brain FCRs for ${ }^{3} \mathrm{H}$-CEt and ${ }^{125} \mathrm{I}-\mathrm{TC}$, because ${ }^{3} \mathrm{H}$-CEt accumulation represents both the selective uptake of CE and HDL-associated CE and uptake of ${ }^{125} \mathrm{I}-\mathrm{TC}$ traces the HDL holo-particle uptake.

Western analysis. Brain regions were homogenized in $10 \mathrm{~mm}$ Tris- $\mathrm{HCl}$, $1 \%(\mathrm{v} / \mathrm{v})$ Triton X-100, $40 \mu \mathrm{M}$ phenylmethylsulfonyl fluoride and complete protease inhibitors (Roche Diagnostics Corp.). Protein concentration in brain tissue and capillaries isolated from brains was determined by the Lowry assay. Equal amounts of total protein were separated by SDS-PAGE, transferred to polyvinylidene difluoride (PVDF) membranes, and probed with either an anti-ABCA1(Wellington et al., 2002), anti-SR-BI (Novus Biologicals), anti-ApoE (Millipore Bioscience Research Reagents), anti-ApoA-I (Biodesign), anti-CYP46A1 (a gift from Dr. D. Russell, University of Texas Southwestern Medical Center, Dallas, TX), anti-GAPDH (Millipore Bioscience Research Reagents), anti-actin or anti-tubulin (Sigma) antibody. Densitometric analysis was performed using NIH ImageJ software.
CSF collection. CSF was isolated from the cisterna magna as previously described (DeMattos et al., 2002). Briefly, the meninges overlying the cisterna magna were exposed and cleaned in anesthetized animals. A $30 \mathrm{G}^{1} / 2$ needle was used to puncture the arachnoid membrane covering the cisterna, and the CSF was collected with a polypropylene narrow bore pipette over a period of $2 \mathrm{~min}$.

ApoA-I, ApoE and albumin analysis in the CSF. Three microliters of CSF per sample were mixed with $10 \times$ nondenaturing loading dye (bromophenol blue, $40 \%$ glycerol and $1 \mathrm{~m}$ Tris, $\mathrm{pH} 6.8$ ) and separated by $6 \%$ native-PAGE, transferred to PVDF membranes and then probed with either 1:500 anti-ApoE (Santa Cruz) or 1:500 anti-ApoA-I (Biodesign) antibody for $2 \mathrm{~h}$. Membranes were washed with PBS-T (PBS with $0.1 \%$ Tween 20) four times for 8 min each and incubated for $1 \mathrm{~h}$ with 1:1000 horseradish peroxidase (HRP)-labeled anti-goat secondary antibody (Santa Cruz) or 1:1000 anti-rabbit antibody (Santa Cruz), respectively. Sizes of particles were determined by comparison with proteins of known molecular diameter in the GE Healthcare Bio-Science native high molecular weight marker.

CSF and blood were collected from control and $A b c a 1^{-B /-B}$ mice. Albumin levels were analyzed using the mouse albumin quantitation kit from Bethyl Laboratories.

Capillary depletion. Brain capillaries were isolated using a modified depletion method from Triguero et al.(Triguero et al., 1990). Mice were anesthetized and perfused with ice-cold PBS for $2 \mathrm{~min}$. Brains were dissected out quickly and meninges were removed. Pooled brains from control and $A b c a 1^{-B /-B}$ mice were homogenized in a glass homogenizer in 2 volumes of physiological buffer (10 mM HEPES, $141 \mathrm{~mm} \mathrm{NaCl}, 4 \mathrm{~mm}$ $\mathrm{KCl}, 1 \mathrm{~mm} \mathrm{NaH}_{2} \mathrm{PO}_{4}, 2.8 \mathrm{mM} \mathrm{CaCl}_{2}, 1 \mathrm{~mm} \mathrm{MgSO}_{4}, 10 \mathrm{~mm}$ D-glucose, protease inhibitors, $\mathrm{pH} 7.4$ ) with 10 strokes on ice. Then 1.5 volumes of cold $26 \%$ dextran were added for a final dextran concentration of $16 \%$ and the tissue was homogenized with 3 more strokes. The homogenate was centrifuged at $1200 \times g$ for $30 \mathrm{~min}$ at $4^{\circ} \mathrm{C}$ in a swinging-bucket rotor (Beckman Coulter). The supernatant containing brain tissue and the pellet containing the capillaries were carefully separated. To ensure that the capillary pellet was not contaminated by brain tissue, the levels of the platelet endothelial cell adhesion molecule-1 (PECAM-1), a BCECs marker, were analyzed by Western blotting.

Behavioral analysis. All animal procedures were conducted in agreement with the guidelines of the Animal Care Committee at the University of British Columbia. Locomotor activity in the open-field apparatus (Med Associates) was analyzed in male control and $A b c a 1^{-B /-B}$ mice at 3 months. Mice were transferred to the procedure room and allowed to acclimatize for $1 \mathrm{~h}$. Each mouse was then placed in the middle of the open-field box and distance traveled, rearing, stereotypic counts and the speed of movement were recorded in a $1 \mathrm{~h}$ session.

Acoustic startle (AS) and prepulse inhibition (PPI) of AS were analyzed at 6 months of age using the startle response system (SR-Lab, San Diego Instruments). Mice were placed into startle chambers and given a 5 min acclimation period with background noise alone (70 dB). Mice were then presented with 100 startle stimuli of noise intensities ranging from background to $120 \mathrm{~dB}$ with a duration of $50 \mathrm{~ms}$, divided into 10 blocks of 10 trials. Each block contained individual trials of each intensity and the trials were pseudorandomized within each block. Intertrial interval was randomized and set between 8 and 32 s. During the PPI test, after the 5 min acclimation period, mice were presented with eight trial blocks. The first and last block consisted of six pulse-alone (120 dB) trials. The other six blocks consisted of six trials each including a no-pulse (background), pulse $(120 \mathrm{~dB})$ and four prepulse + pulse trials with prepulse intensities set at 72,74, 78 or $86 \mathrm{~dB}$ for a duration of $20 \mathrm{~ms}$ and preceding pulse by $20 \mathrm{~ms}$. Percentage PPI was calculated as [ $1-$ (average prepulse startle amplitude - no pulse)/(average pulse startle amplitude - no pulse) $] \times 100$.

Confocal microscopy. Mice were deeply anesthetized and perfused with $4 \%$ paraformaldehyde (PFA). Brains were dissected and left overnight in $4 \%$ PFA before being transferred into $30 \%$ sucrose solution. Brains were frozen and sliced on the cryostat into $25 \mu \mathrm{m}$ coronal sections. Free floating sections were blocked in $1 \%$ goat serum in PBS with $0.3 \%$ Triton $\mathrm{X}-100$ for $1 \mathrm{~h}$. Sections were incubated with primary antibodies (rabbit anti-CYP46A1, gift from Dr. D. Russell, 1:200), rat anti-glial fibrillary 
A

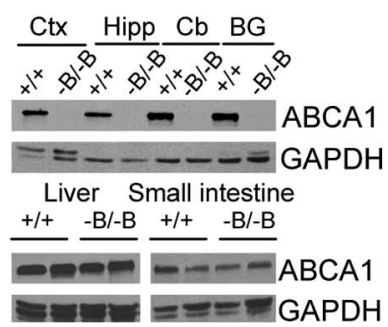

B

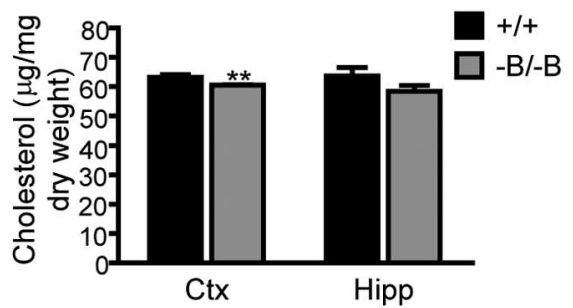

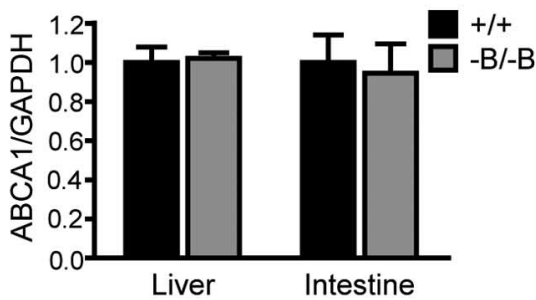

C

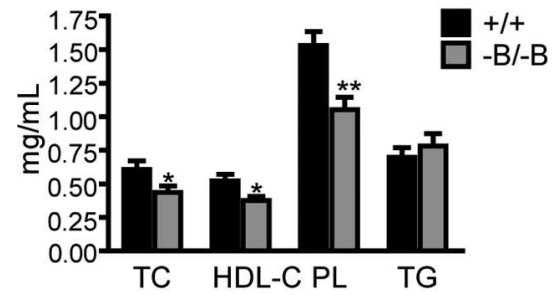

Figure 1. Brain and plasma cholesterol levels in $A b c a 1^{-B /-B}$ mice. $A$, Selective loss of $A B C A 1$ in the brains of $A b c a 1^{-B /-B}$ mice. Tissue lysates from different brain regions, liver, and small intestine from control $(+/+)$ and $A b c a 1^{-B /-B}$ mice were analyzed by immunoblotting using a polyclonal antibody for ABCA1. GAPDH was used as a loading control. Densitometry analysis of the liver and intestine blot is shown (means \pm SEM, $n=4$ ). $\boldsymbol{B}$, Cholesterol levels in cortex and hippocampus were analyzed by gas-liquid chromatographic mass spectrometry. ${ }^{* *} p<0.01$ versus control littermates, $n=6$ per group. $\boldsymbol{C}$, Levels of total cholesterol (TC), HDL-cholesterol (HDL-C), phospholipids (PL), and triglycerides (TG) in plasma measured by enzymatic assays. ${ }^{*} p<0.05$, versus control littermates, $n=12-20$ per group. Ctx, Cortex; Hipp, hippocampus; Cb, cerebellum; BG, basal ganglia.

acidic protein (GFAP) (Zymed, 1:50) or rabbit anti-synaptotagmin (Stressgen, $1: 200$ ) in $1 \%$ goat serum, PBS and $0.3 \%$ Triton X-100 overnight at room temperature. Sections were then washed three times in PBS for $10 \mathrm{~min}$ and incubated with appropriate secondary fluorescent antibodies (goat anti-rabbit Alexa Fluor 488 or goat anti-rat Alexa Fluor 594, 1:1000) in PBS for $1 \mathrm{~h}$, followed by three 10 min washes in PBS. Sections were dried, mounted and imaged on a Zeiss 510 Meta laser scanning confocal microscope.

Electron microscopy. Five mice per group were anesthetized and injected with $15 \mu \mathrm{l}$ of heparin intracardially. Mice were perfused with $4 \%$ PFA and $0.125 \%$ glutaraldehyde for $20 \mathrm{~min}$ at a rate of $6 \mathrm{ml} / \mathrm{min}$. Brains were dissected, left overnight in 4\% PFA and $0.125 \%$ glutaraldehyde and cut into $400 \mu \mathrm{m}$ sections on a vibratome. Postfixing, embedding, sectioning and staining were performed at the University of British Columbia BioImaging facility. Briefly, $1 \mathrm{~mm}^{2}$ tissue blocks from layers five and six of the motor cortex (1.1 mm from bregma) were cut out, rinsed in 0.1 M sodium cacodylate buffer and secondary fixed in $1 \%$ osmium tetroxide with $1.5 \%$ potassium ferricyanide in $0.1 \mathrm{~m}$ sodium cacodylate for $2 \mathrm{~h}$. Tissue was washed two times in distilled water and stained en bloc with $2 \%$ uranyl acetate for $45 \mathrm{~min}$. Samples were dehydrated in a series of ethanol dilutions and transferred to $100 \%$ propylene oxide for $15 \mathrm{~min}$, followed by graded resin infiltration and embedding. Ultrathin sections were prepared on a Leica Ultracut $\mathrm{T}$ using 45 degree diamond histoknife. Thin sections were counterstained with Sato's lead. Images were taken using a Hitachi H7600 Transmission Electron Microscope and analyzed using Image J. Synapse numbers were identified at a magnification of $15,000 \times$ in a total area of $2000 \mu \mathrm{m}^{2}$ per animal. Synapses were identified based on synaptic vesicle and postsynaptic density morphology as either asymmetric (excitatory synapses, with round vesicles and a thick postsynaptic density) or symmetric (inhibitory synapses, with presence of flattened vesicles and no thickening of postsynaptic membrane). Synaptic vesicle numbers were counted manually at $50,000 \times$ and were classified either as docked (in close proximity to the presynaptic membrane) or reserve pool. A total of 150 excitatory synapses per each mouse were counted.

Statistical analysis. All data are presented as means \pm SEM. Differences between groups were analyzed using Student's $t$ test. Correlation between fraction of plasma ${ }^{3} \mathrm{H}$-CEt and brain ${ }^{3} \mathrm{H}-\mathrm{CEt}$ uptake was analyzed using linear regression. AS and PPI data were analyzed by two-way repeated measures ANOVA with genotype as a between-subjects factor and AS or PPI as repeated-measures factor. Least-squares differences post hoc comparison was used to detect differences at the $p<0.05$ level.

\section{Results}

Brain ABCA1 impacts plasma cholesterol levels $A b c a 1^{-B /-B}$ mice were generated by crossing loxP-flanked (floxed) ABCA1 mice (Timmins et al., 2005) with transgenic mice expressing Cre recombinase under the control of the neuronal and glial specific nestin promoter (Tronche et al., 1999). Abca1 ${ }^{-B /-B}$ mice were born at expected Mendelian frequencies, were fertile and did not differ in weight from littermate controls (floxed ABCA1 mice). Immunoblot analysis showed an absence of ABCA1 protein in all regions of the brain that were examined (Fig. $1 A$ ). Nestin expression has been reported in some progenitor cells such as liver oval cells serving as hepatocyte precursors in response to liver injury (Gleiberman et al., 2005). Because hepatic as well as intestinal ABCA1 are critical contributors to plasma HDL levels (Timmins et al., 2005; Brunham et al., 2006), we analyzed ABCA1 levels in these organs and found that they were normal (Fig. 1A). ABCG1 and ABCG4 are other cholesterol transporters expressed in the brain. No change in ABCG1 and ABCG4 mRNA levels were found in the brains of $A b c a 1^{-B /-B}$ mice (supplemental Fig. 1, available at www.jneurosci.org as supplemental material).

To examine the specific impact of brain ABCA1 on central and peripheral cholesterol homeostasis, we measured cholesterol levels in cortex and hippocampus, areas of high ABCA1 expression (Tachikawa et al., 2005) and in plasma of $A b c a 1^{-B /-B}$ mice. Reduced levels of cholesterol were found in $A b c a 1^{-B /-B}$ cortex compared with control littermates (Fig. $1 B$ ). No difference in brain weight was observed (data not shown). Interestingly, this was associated with a significant reduction in plasma cholesterol levels, including total cholesterol and HDL-cholesterol (Fig. 1C). Consistent with decreased HDL cholesterol, plasma phospholipid levels were reduced in $A b c a 1^{-B /-B}$ mice. The levels of triglycerides, which are associated with larger lipoprotein particles and chylomicrons, remained unchanged (Fig. 1C). This demonstrates that selective loss of brain ABCA1 activity reduced the levels of circulating cholesterol by $\sim 25 \%$ or $170 \mu \mathrm{g}$ per $\mathrm{ml}$ of plasma.

\section{Brain cholesterol and plant sterol uptake from plasma are increased in $A b c a 1^{-B /-B}$ mice}

Because the brain normally contributes very little to plasma cholesterol levels (Dietschy and Turley, 2004), a reduction in cholesterol transport from the brain because of the absence of ABCA1 was not expected to result in a significant decrease in plasma total and HDL cholesterol levels. We therefore hypothesized that uptake of circulating cholesterol to brain may be increased in $A b c a 1^{-B /-B}$ mice to compensate for cholesterol transport deficits 
in the CNS, ultimately resulting in decreased plasma cholesterol levels.

To further investigate this hypothesis, we used a radioisotope labeling technique that allows HDL metabolism to be monitored in vivo (Pittman and Taylor, 1986). This technique uses nonhydrolyzable radioactive tracers which become trapped in tissues after uptake. This allows for the measurement of catabolism of HDL by specific tissues without the release of free label into plasma (Glass et al., 1983a,b; Pittman et al., 1983). HDL cholesterol is taken up by tissues either through HDL holo-particle internalization or selective uptake of esterified cholesterol (cholesteryl ester, CE) via scavenger receptor BI (SR-BI) (Acton et al., 1996). Mice were injected with murine HDL particles double labeled with ${ }^{125} \mathrm{I}$-TC and ${ }^{3} \mathrm{H}$-CEt. ${ }^{125} \mathrm{I}-\mathrm{TC}$ labels HDL apolipoproteins and ${ }^{3} \mathrm{H}$-CEt traces the CE moieties of HDL (Pittman and Taylor, 1986). ${ }^{125}$ I-TC traces the metabolism of HDL holo-particles and the difference between uptake rates of ${ }^{3} \mathrm{H}$-CEt and ${ }^{125} \mathrm{I}-\mathrm{TC}$ reflects tissue-specific selective uptake of CE from HDL particle (Pittman et al., 1987).

The fraction of ${ }^{3} \mathrm{H}$ activity (cpm) remaining in plasma $24 \mathrm{~h}$ after injection of labeled HDL was reduced by $28 \%$ in $A b c a 1^{-B /-B}$ compared with control mice (Fig. $2 A$ ), suggesting that uptake of ${ }^{3} \mathrm{H}$-CEt labeled $\mathrm{CE}$ from plasma was higher in $A b c a 1^{-B /-B}$ mice. Interestingly, this decrease in plasma ${ }^{3} \mathrm{H}-\mathrm{CEt}$ labeled CE parallels the $27 \%$ reduction in HDL cholesterol observed in $A b c a 1^{-B /-B}$ mice (Fig. $1 C)$. There was no difference in the plasma fraction of ${ }^{125} \mathrm{I} \mathrm{cpm}$ at $24 \mathrm{~h}$ indicating that increased ${ }^{3} \mathrm{H}$-CEt clearance in $A b c a 1^{-B /-B}$ mice was due to selective ${ }^{3} \mathrm{H}$-CEt uptake and not increased HDL holo-particle uptake.

Because the tracer activity found in the brain is normally very low (Brundert et al., 2005), we measured ${ }^{125} \mathrm{I}$-TC and ${ }^{3} \mathrm{H}$-CEt uptake in whole brains instead of discrete regions to detect the maximum radioactivity. Brain uptake rate of total ${ }^{3} \mathrm{H}$-CEt, measured by brain FCR (Pittman and Taylor, 1986), was higher in $A B C A 1^{-B /-B}$ than in control mice (Fig. $2 B$ ). In contrast, no change in brain FCR for ${ }^{125} \mathrm{I}$-TC was observed in $A b c a 1^{-B /-B}$ mice confirming that HDL holo-particle uptake was not affected. The rate of selective uptake of ${ }^{3} \mathrm{H}$-CEt labeled CE was increased by $>2$-fold in $A b c a 1^{-B /-B}$ compared with control mice (Fig. 2C). We observed a significant negative correlation $\left(r^{2}=0.71, p=\right.$ 0.01 ) between the fraction of ${ }^{3} \mathrm{H}$ activity found in plasma $24 \mathrm{~h}$ after injection and brain uptake of ${ }^{3} \mathrm{H}$-CEt (Fig. 2D), indicating that reduced plasma ${ }^{3} \mathrm{H}$-CEt levels were associated with increased brain ${ }^{3} \mathrm{H}$-CEt uptake. Importantly, these changes in cholesterol uptake were specific to the brain as no differences in rates of ${ }^{3} \mathrm{H}-\mathrm{CEt}$ and ${ }^{125} \mathrm{I}$-TC uptake were observed between control and $A b c a 1^{-B /-B}$ mice in other tissues including the liver $(2.2 \pm 0.6 \mathrm{vs}$ $2.1 \pm 0.1$ pools $/ \mathrm{d}, p=0.9)$ and adrenals $(0.018 \pm 0.002 \mathrm{vs}$ $0.012 \pm 0.002$ pools $/ \mathrm{d}, p=0.1)$. These findings demonstrate that the metabolism of plasma HDL is altered in $A b c a 1^{-B /-B}$ mice, such that selective uptake of HDL-associated CE is increased specifically in the brains of these mice.

To further validate these findings, we investigated whether
B

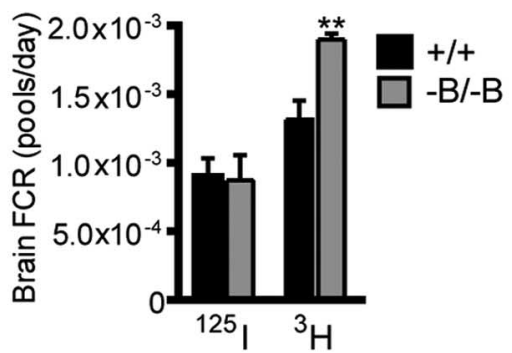

D

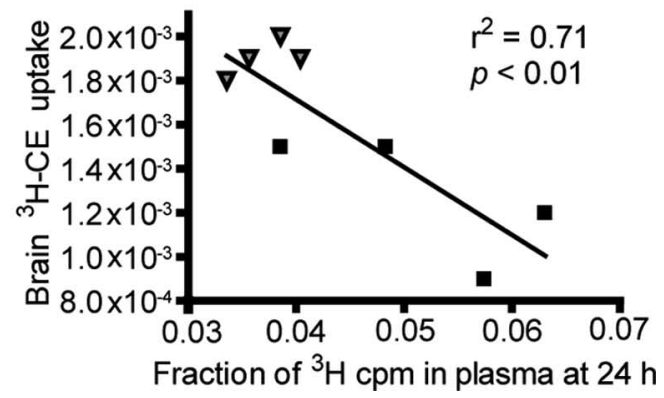




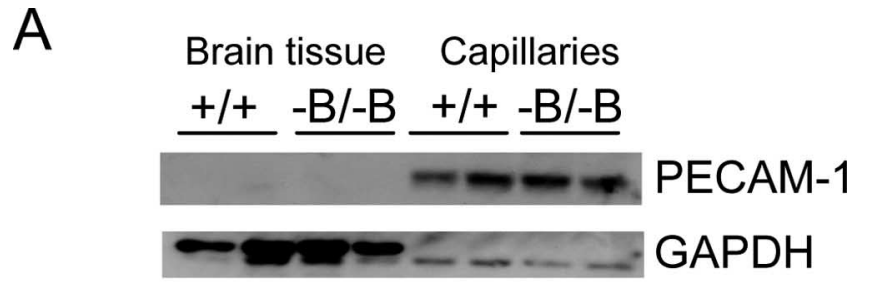

B

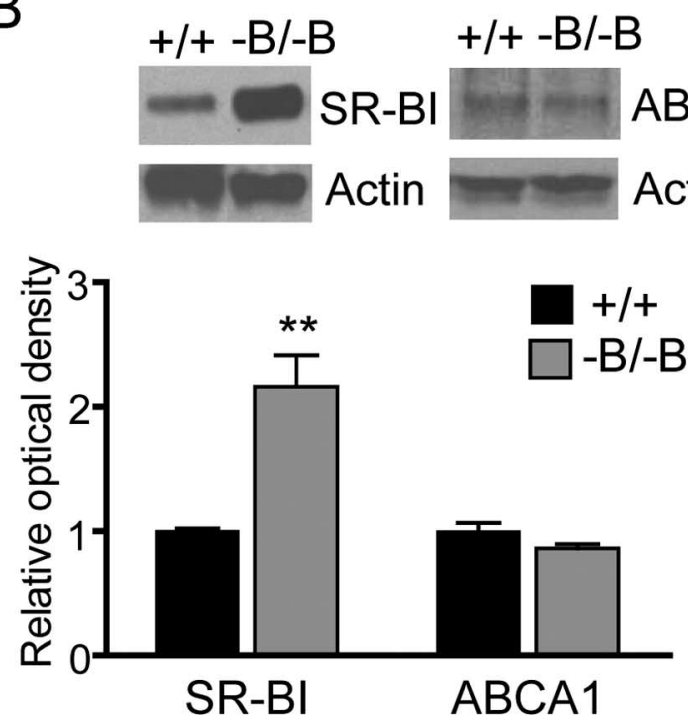

Figure 4. Levels of $S R-B l$ in brain capillaries from $A b c a 1^{-B /-B}$ mice. Brain capillaries were isolated from control and $A b c a 1^{-B /-B}$ mice. $A$, A representative of a Western blot for the BCEC marker PECAM-1. PECAM-1 signal was found in the isolated capillaries (lanes 5-8) in control and $A b c a 1^{-B /-B}$ mice but not in the capillary-depleted brain tissue (lanes 1-4). GAPDH was used as loading control. $B$, Capillaries were immunoblotted for SR-BI and ABCA1 ( $n=4$ per group). Actin was used as a loading control. Graph shows means \pm SEM of densitometric measurements of SR-BI and ABCA1 signal intensity. Blots are representative of several experiments. ${ }^{* *} p<0.01$ compared with control mice.

reduction in plasma sitosterol because of the 100-fold higher sitosterol levels in plasma compared with brain.

To exclude global blood-brain barrier disruption as a possible cause for increased brain cholesterol and sitosterol uptake in $A b c a 1^{-B /-B}$ mice, the albumin CSF/plasma ratio was measured. CSF albumin is derived from plasma and increased permeability of the blood-brain barrier would be expected to increase the albumin CSF/plasma concentration quotient (Bowman et al., 2007). There was no difference in the CSF/plasma albumin ratio between control and $A b c a 1^{-B /-B}$ mice $(0.0023 \pm 0.0003$ vs $0.0018 \pm 0.0002, p=0.18)$, indicating that the integrity of the blood-brain barrier was not compromised.

\section{$A b c a 1^{-B /-B}$ mice have increased levels of SR-BI in brain capillaries and ApoA-I in brain and CSF}

SR-BI mediates the selective cellular uptake of CE from HDL particles (Acton et al., 1996). Because functional SR-BI is expressed in BCECs (Goti et al., 2001), SR-BI may facilitate increased brain CE uptake in $A b c a 1^{-B /-B}$ mice. Western blot analysis of capillaries isolated from whole brains demonstrated a twofold increase in SR-BI protein levels in $A b c a 1^{-B /-B}$ mice (Fig. $4 B)$. ABCA1 also increases flux of cholesterol across membranes, but we did not observe a change in the levels of ABCA1 in the BCECs of $A b c a 1^{-B /-B}$ mice (Fig. $4 B$ ) suggesting that upregula-
A

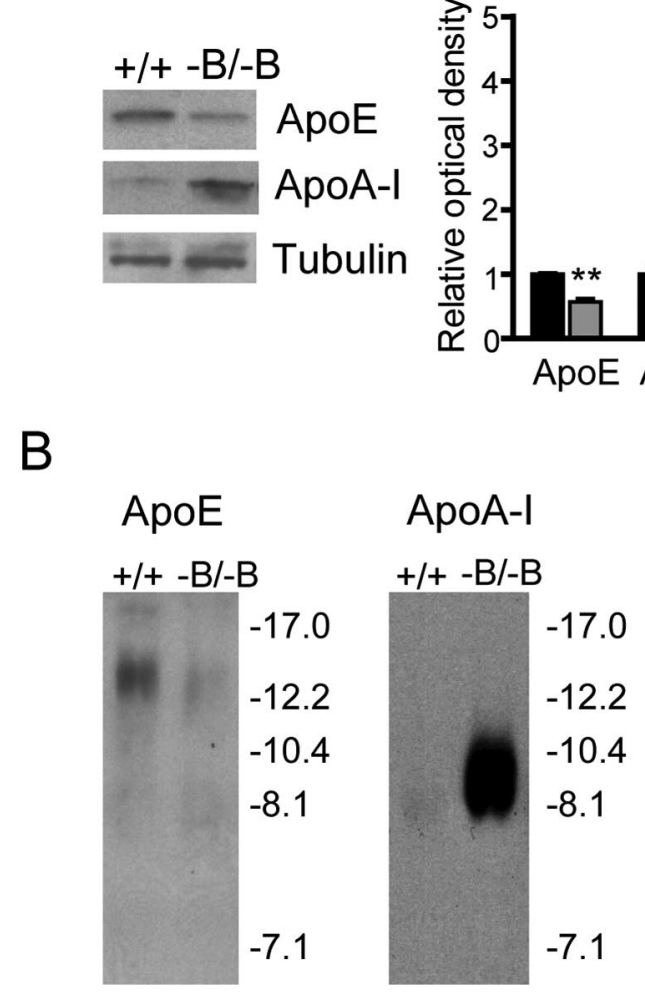

Figure 5. ApoE and ApoA-l levels in the brain and $C S F$ of $A b c a 1^{-B /-B}$ mice. $A$, Immunoblots of brain tissue from control and $A b c a 1^{-B /-B}$ mice using $A p o E$ and $A p o A-I$ specific antibodies. Tubulin was used as a loading control. Densitometry analysis demonstrated a $40 \%$ decrease in $A p o E$ and a $250 \%$ increase in ApoA-I signal intensity in $A b c a 1^{-B /-B}$ mice compared with control mice. Graph shows means \pm SEM $\left({ }^{*} p<0.05,{ }^{* *} p<0.01, n=3\right.$ per group). $B$, CSF samples $(3 \mu \mathrm{l})$ were run on a nondenaturing gel and probed for $A p o E$ (left) and ApoA-I (right).

tion of ABCA1 at the blood-brain barrier is not required for increased brain cholesterol uptake.

We measured the levels of brain ApoE and ApoA-I to determine whether these apolipoproteins are involved in increased brain cholesterol uptake in $A b c a 1^{-B /-B}$ mice. In agreement with the role for ABCA1 in the secretion of ApoE from astrocytes and the regulation of brain ApoE levels (Hirsch-Reinshagen et al., 2004; Wahrle et al., 2004), Western blot analysis demonstrated reduced levels of ApoE in the brains of $A b c a 1^{-B /-B}$ mice (Fig. $5 A$ ). In contrast, the levels of brain ApoA-I were significantly elevated. Because ApoA-I is not synthesized in the CNS (Elshourbagy et al., 1985) and we found no detectable levels of ApoA-I mRNA in brains of $A b c a 1^{-B /-B}$ mice (data not shown), this increase is either due to increased ApoA-I uptake from peripheral circulation or secretion from BCECs. However, as shown in Figure $2 B$, there was no change in the uptake of ${ }^{125} \mathrm{I}$-TC labeled HDL apolipoprotein in $A b c a 1^{-B /-B}$ mice. Considering that most of the apolipoprotein content in HDL is ApoA-I, this suggests that the major source of elevated brain ApoA-I in $A b c a 1^{-B /-B}$ mice are likely BCECs. However, we were unable to detect a consistent and statistically significant increase in ApoA-I protein levels in BCECs by Western blotting (data not shown). This may be due to rapid secretion of ApoA-I from BCECs and different rates of secretion in individual mice.

In mice, ApoE and ApoA-I in the CSF associate with HDL particles $10-17$ and $10 \mathrm{~nm}$ in diameter, respectively (Wahrle et al., 2004). We analyzed the levels and size distribution of CSF ApoE and ApoA-I containing lipoproteins by nondenaturing gel 
electrophoresis. As expected, ApoE levels were reduced in CSF of $A b c a 1^{-B /-B}$ mice (Fig. 5B). The levels of CSF ApoA-I, however, were considerably elevated. ApoA-I was associated with HDL particles 8-10 $\mathrm{nm}$ in diameter, similar to those in control animals and as reported in wild-type mice (Wahrle et al., 2004). This demonstrates that although ApoA-I levels are significantly increased in the brain and CSF of $A b c a 1^{-B /-B}$ mice, this ApoA-I is predominately associated with small, less lipidated HDL particles. Notably, the total levels of cholesterol in the CSF were similar in control $(9.5 \pm 0.5 \mu \mathrm{g} / \mathrm{ml})$ and $A b c a 1^{-B /-B}$ mice $(8.7 \pm 0.7 \mu \mathrm{g} / \mathrm{ml}, \mathrm{p}=0.4)$.

\section{Brain cholesterol turnover is increased in Abca ${ }^{-\mathrm{B} /-\mathrm{B}}$ mice}

Cholesterol transport across the basolateral membrane of cultured BCECs can be induced in vitro by the brain cholesterolspecific metabolite and nuclear liver-Xreceptor agonist 24S-OH cholesterol (Panzenboeck et al., 2006). This suggests that elevated brain 24S-OH cholesterol production is a potential mechanism for activating cholesterol transport across the blood-brain barrier in $A b c a 1^{-B /-B}$ mice.

Supporting this hypothesis is our observation that $A b c a 1^{-B /-B}$ mice displayed an increased ratio of $24 \mathrm{~S}-\mathrm{OH}$ cholesterol to cholesterol (Fig. 6A, left) compared with control mice in both cortex and hippocampus. Plasma levels of $24 \mathrm{~S}-\mathrm{OH}$ cholesterol were also increased in $A b c a 1^{-B /-B}$ mice (Fig. $6 A$, right).

There was no change in CYP46A1 mass in the brains of $A b c a 1^{-B /-B}$ mice (Fig. $6 B)$, suggesting that increased $24 \mathrm{~S}-\mathrm{OH}$ cholesterol production is either a result of increased neuronal CYP46A1 enzymatic activity or reciprocal changes in CYP46A1 expression in neurons and glia. Although CYP46A1 is a neuron-specific enzyme (Lund et al., 1999), glial CYP46A1 expression was reported in brains of Alzheimer patients (Brown, III et al., 2004). Immunofluorescence analysis of brain sections from wild-type mice indicated that in addition to distribution in neurons (data not shown), CYP46A1 colocalizes with the astrocytic marker GFAP (Fig. 6C) indicating that glial cells can also express CYP46A1 and may therefore contribute to brain $24 \mathrm{~S}-\mathrm{OH}$ cholesterol production.

Brain cholesterol homeostasis is under tight regulatory control whereby changes in cholesterol metabolism are reflected in changes in synthesis (Lund et al., 2003). Because of the exquisite regulation of brain cholesterol balance and the findings of reduced cortical cholesterol levels and increased metabolism to $24 \mathrm{~S}-\mathrm{OH}$ cholesterol, we next determined whether this was accompanied by alterations in cholesterol synthesis in $A b c a 1^{-B /-B}$ mice. To assess this, the levels of cholesterol biosynthetic intermediates (Lütjohann et al., 2002) were measured in brain and mice.
B
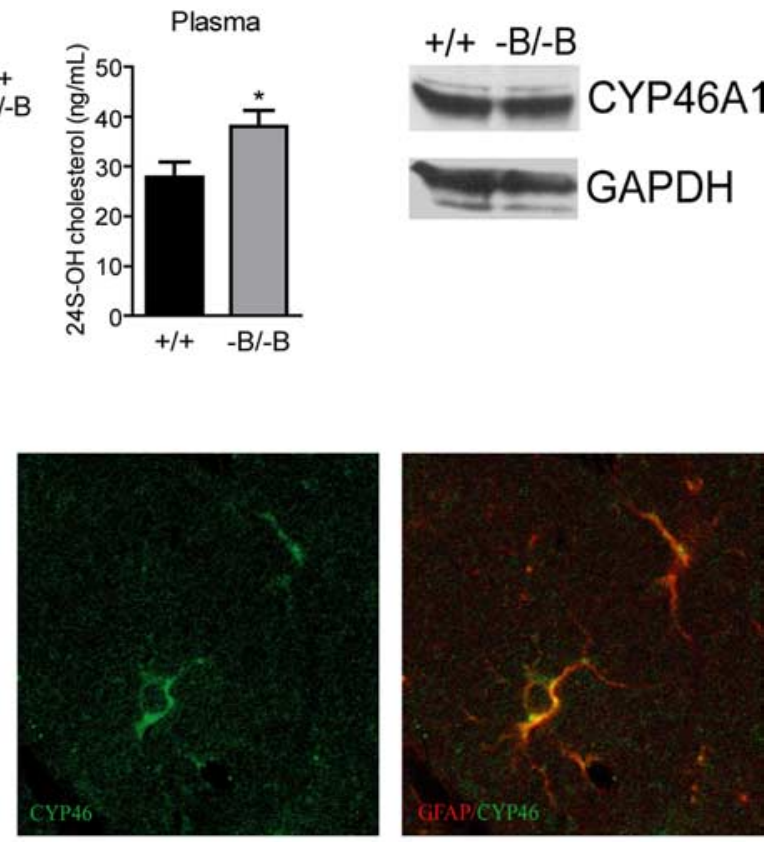

Brain
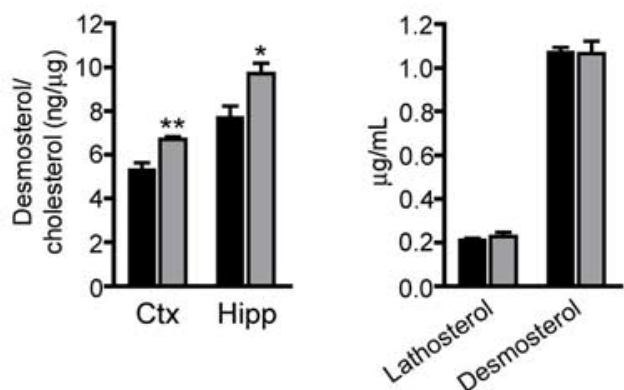

Figure 6. Brain cholesterol turnover in $A b c a 1^{-B /-B}$ mice. Brain and plasma levels of cholesterol metabolite $24 S-0 \mathrm{H}$ cholesterol and cholesterol precursors lathosterol and desmosterol were analyzed by GC-MS ( $n=6$ per group, means \pm SEM). $A$, Left, The ratio of $24 \mathrm{~S}-\mathrm{OH}$ cholesterol to cholesterol in cortex and hippocampus of control and $\mathrm{ABCA} 1^{-\mathrm{B} /-\mathrm{B}}$ mice. $\boldsymbol{A}$, Right, Plasma levels of $24 \mathrm{~S}-\mathrm{OH}$ cholesterol. $\boldsymbol{B}$, Western blot shows cortical CYP46A1 levels (representative of several experiments). $\boldsymbol{C}$, Confocal (green). Scale bar, $10 \mu \mathrm{m}$. D, Graphs show ratios of lathosterol to cholesterol and desmosterol to cholesterol in hippocampus and cortex as well as plasma lathosterol and desmosterol levels. Ctx, Cortex; Hipp, hippocampus. ${ }^{*} p<0.05,{ }^{* *} p<0.01$ versus control

plasma. The lathosterol to cholesterol ratio was significantly increased in $A b c a 1^{-B /-B}$ mice compared with control mice in hippocampus (Fig. $6 D$, left). Higher ratios of desmosterol to cholesterol were observed in $\mathrm{ABCA} 1^{-\mathrm{B} /-\mathrm{B}}$ compared with control mice in cortex and hippocampus (Fig. 6D, middle). Plasma lathosterol and desmosterol levels were unchanged, indicating that the increase in cholesterol synthesis was specific to the brain (Fig. 6D, right). Lanosterol is the first sterol precursor in the cholesterol biosynthetic pathway (Lütjohann et al., 2002). No change in the lanosterol to cholesterol ratio in the brain was observed in $A b c a 1^{-B /-B}$ mice (data not shown), suggesting that cholesterol biosynthesis was selectively increased in post-lanosterol steps, when the biosynthetic pathway diverges and continues via the lathosterol and desmosterol routes (Lütjohann et al., 2002).

We considered the possibility that increased brain sterol pre- 
cursor to cholesterol levels could be a result of reduced conversion of lathosterol and desmosterol to cholesterol. However, reduced desmosterol conversion would be associated with reduced levels of 3beta-hydroxysterol Delta24-reductase (DHCR24) also known as seladin-1 and increased levels of all precursors carrying a double bond at C-24 including lanosterol (Waterham et al., 2001). We also measured the levels of dihydrolanosterol, the post-lanosterol step and a lathosterol precursor (Lindenthal et al., 2002) and found no changes in $A b c a 1^{-B /-B}$ cortex or hippocampus (data not shown). This suggests that the increase in cholesterol precursors is not due to their decreased degradation.

\section{$A b c a 1^{-B /-B}$ mice exhibit abnormal behavior and synaptic structure}

In view of the critical role of cholesterol in brain development, synaptogenesis and synaptic activity (Mauch et al., 2001; Dietschy and Turley, 2004), changes in brain cholesterol homeostasis were postulated to influence behavioral function and synaptic development in $A b c a 1^{-B /-B}$ mice. We assessed a wide range of behaviors in control and $A b c a 1^{-B /-B}$ mice. Spontaneous locomotor activity was attenuated in $A b c a 1^{-B /-B}$ mice in the openfield test (Fig. 7A), including a reduction in horizontal (distance traveled) and vertical (number of rears) activity. Stereotypic behavior and movement velocity were also reduced in $A b c a 1^{-B /-B}$ mice (stereotypic counts: $10,060 \pm 329$ in control vs $6896 \pm 378$ in $A b c a 1^{-B /-B}$ mice, $p<0.001$; velocity: $47.55 \pm 2.6 \mathrm{~cm} / \mathrm{min}$ in control vs $35.2 \pm 1.4 \mathrm{~cm} / \mathrm{min}$ in $A b c a 1^{-B /-B}$ mice, $p<0.0001$ ). Although motor coordination measured by rotarod performance was normal at 3 months of age, $A b c a 1^{-B /-B}$ mice showed reduced latency to fall at 9 months (data not shown). No changes in spatial learning in the Morris water maze were observed between control and $A b c a 1^{-B /-B}$ mice (data not shown).

Sensorimotor function was assessed with the AS and the PPI of AS tests. A significant reduction in AS magnitude was observed in $A b c a 1^{-B /-B}$ mice at high intensity startle stimuli (110 dB-120 dB) (Fig. $7 B$ ). Conversely, PPI was increased in $A b c a 1^{-B /-B}$ mice at $2 \mathrm{~dB}, 4 \mathrm{~dB}$ and $8 \mathrm{~dB}$ prepulse intensities (Fig. 7C). The behavioral data indicate that loss of brain ABCA1 affects motor and sensorimotor functions that are mainly controlled by forebrain structures.

We next investigated whether synaptic alterations in the cortex are associated with disturbances in motor and sensorimotor function in the absence of brain ABCA1. Immunofluorescence analysis of synaptotagmin, a presynaptic protein associated with synaptic vesicles, revealed changes in neuronal distribution including reduced staining intensity of synaptic puncta in cortex of $A b c a 1^{-B /-B}$ mice (Fig. $8 A$ ) suggesting a possible presynaptic deficit. We therefore examined the synaptic ultrastructure in the cortex using electron microscopy to analyze the numbers of synapses and synaptic vesicles (Fig. 8 B). Quantitative ultrastructural analysis revealed a $16 \%$ decrease in the number of synapses in $A b c a 1^{-B /-B}$ mice (Fig. $8 C$ ), which could be attributed to the reduction in the number of excitatory synapses. Synapses with perforated postsynaptic densities represent an intermediate between a continuous synapse and a divided synapse that has formed new synaptic contacts on two separate spines of the same dendrite (Carlin and Siekevitz, 1983). The proportion of synapses containing a perforated postsynaptic density was $20 \%$ in control mice but only $12 \%$ in $A b c a 1^{-B /-B}$ mice (Fig. $8 D$ ). Abcal ${ }^{-B /-B}$ mice also had an $18 \%$ decrease in the average number of synaptic vesicles per synapse in the reserve vesicle pool and a reduction in the number of docked vesicles (Fig. $8 E$ ).

Hence, attenuated locomotor activity and altered sensorimo-
A

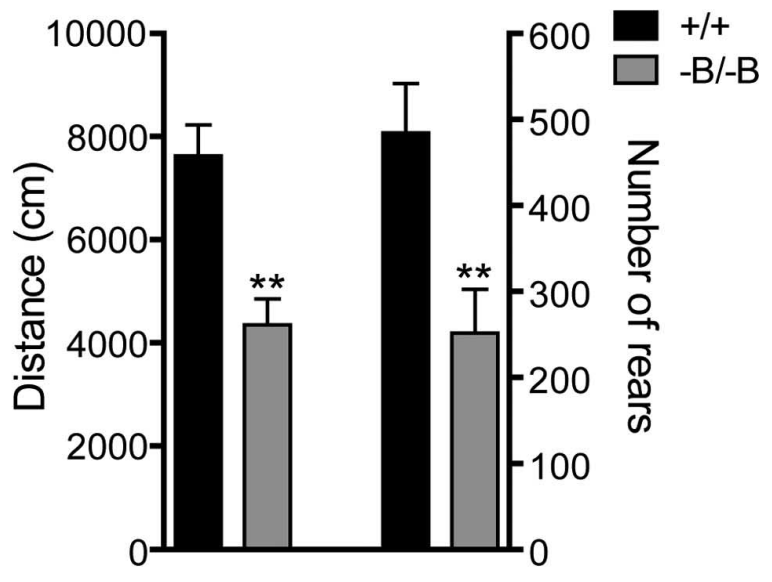

B

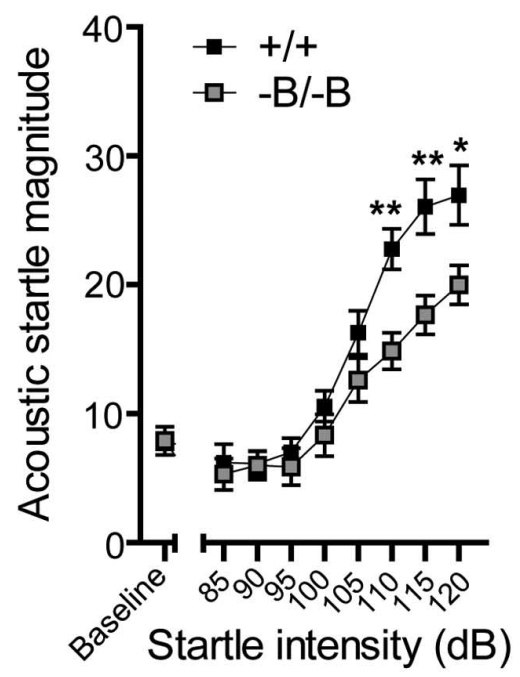

C

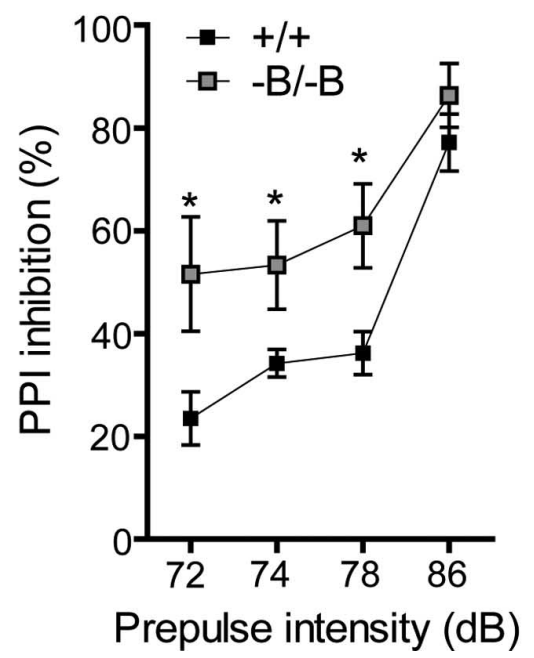

Figure 7. Behavioral function in $A b c a 1^{-B /-B}$ mice. $A$, Spontaneous locomotor activity was measured in 3-month-old control and $A b c a 1^{-B /-B}$ mice during a $1 \mathrm{~h}$ session in an open field chamber. Specific aspects of locomotor activity including horizontal (distance) and vertical (number of rears) activity were analyzed ( $n=11-12)$. Data show means \pm SEM B, Acoustic startle response at various startle intensities. C, PPI of acoustic startle measured at prepulse intensities of 72,74,78, and $86 \mathrm{~dB}$ ( $n=11$ per group). ${ }^{*} p<0.05,{ }^{* *} p<0.01,{ }^{* * *} p<0.001$ compared with control mice. 
tor function in $A b c a 1^{-B /-B}$ mice is associated with reduced number of excitatory synapses and vesicles in the cortex.

\section{Discussion}

We report that changes in brain cholesterol homeostasis induced by loss of brain ABCA1 activity can lead to alterations in cholesterol transport across the bloodbrain barrier. $A b c a 1^{-B /-B}$ mice demonstrate increased brain uptake of esterified cholesterol from plasma HDL which is associated with reduced plasma HDL cholesterol levels. Inactivation of brain ABCA1 also leads to motor and sensorimotor behavioral and synaptic changes. These findings implicate ABCA1 as a key regulator of brain cholesterol homeostasis in addition to its established role in the periphery and demonstrate a role for ABCA1 in the regulation of neuronal function.

The brain cholesterol pool separates from the rest of the body during the formation of the blood-brain barrier (Dietschy and Turley, 2004). CNS relies on in situ cholesterol synthesis and efficient transport and recycling mechanisms (Dietschy and Turley, 2004). A key unexpected finding is that $A b c a 1^{-B /-B}$ mice have reduced plasma HDL cholesterol levels. Impaired cholesterol efflux from the CNS cannot explain this reduction because of the negligible contribution of the brain to circulating cholesterol concentration (Björkhem and Meaney, 2004; Dietschy and Turley, 2004). We previously demonstrated that the liver and intestine are major contributors to plasma HDL (Timmins et al., 2005; Brunham et al., 2006) and hepatic and intestinal ABCA1 levels were unaffected in $A b c a 1^{-B /-B}$ mice. The reduced fraction of labeled $\mathrm{CE}$ in plasma in $A b c a 1^{-B /-B}$ mice after $24 \mathrm{~h}$ points to increased HDL CE uptake from plasma. We hypothesized that there is increased brain cholesterol uptake from plasma HDL in $A b c a 1^{-B /-B}$ mice to compensate for the reduction in brain cholesterol concentration highlighting the evolutionary requirement to maintain normal cholesterol homeostasis in the brain. There is no significant brain cholesterol uptake from plasma under conditions of normal brain cholesterol metabolism (Dietschy and Turley, 2004) despite the fact that BCEC basolateral and apical membranes express proteins involved in cholesterol and lipoprotein transport including ABCA1, SR-BI and low density lipoprotein (LDL) receptor (Dehouck et al., 1997; Goti et al., 2001; Panzenboeck et al., 2002). Uptake and transport of HDL-associated esterified cholesterol (Goti et al., 2001)
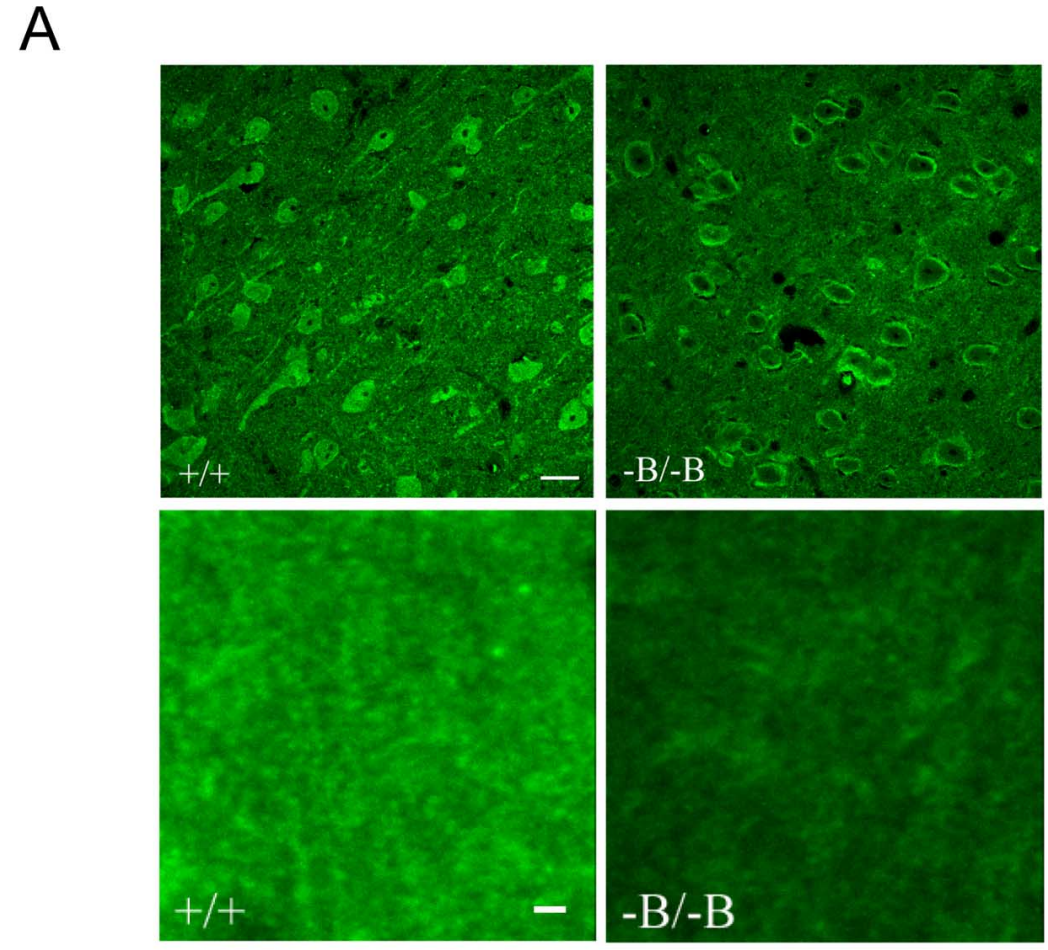

B
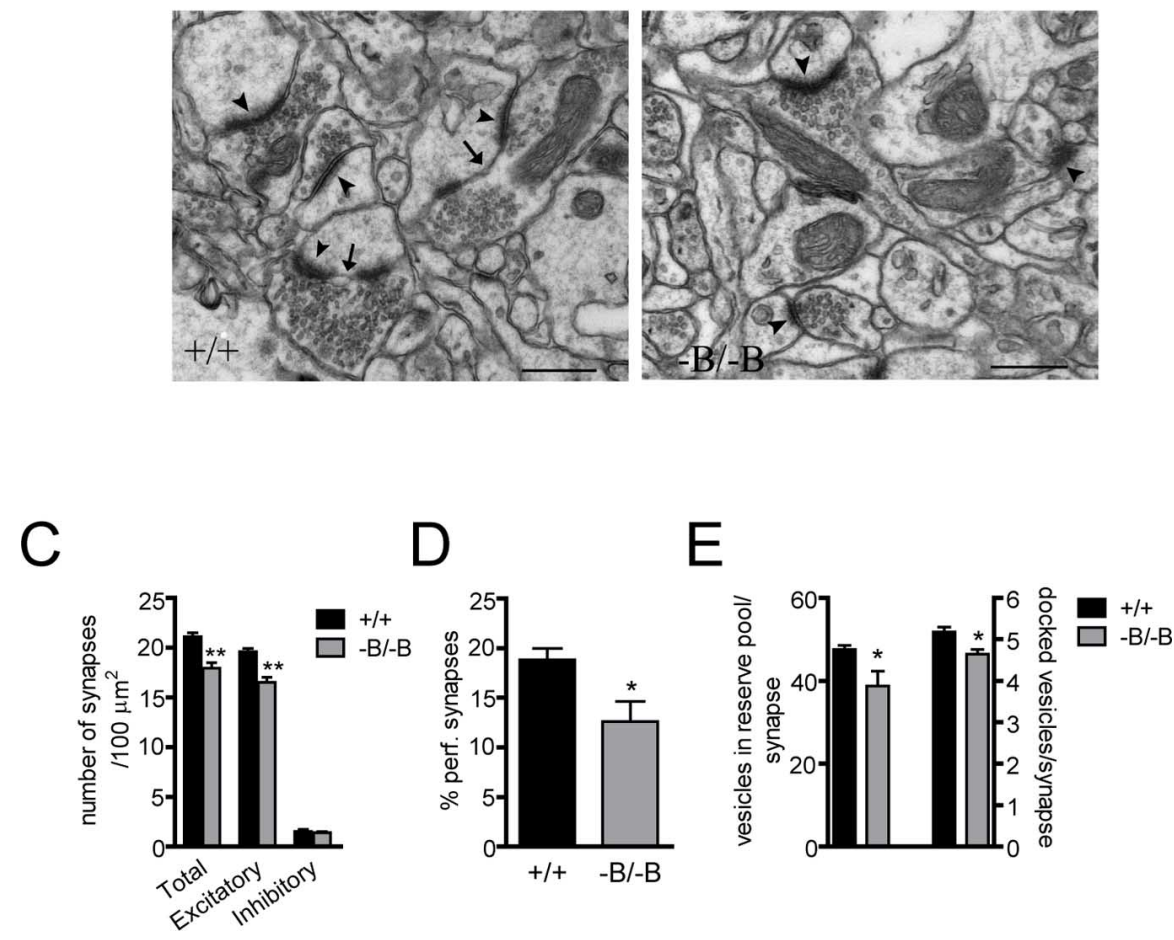

Figure 8. Morphological and ultrastructural synaptic analysis in $A b c a 1^{-B /-B}$ mice. $A$, Confocal images showing neuronal synaptotagmin immunofluorescence in the cortex of control and $A b c a 1^{-B /-B}$ mice. Top images show neuronal synaptotagmin distribution and bottom images show synaptic puncta staining at high magnification. Scale bar, top images: $10 \mu \mathrm{m}$; bottom images: $2 \mu \mathrm{m}$. $\boldsymbol{B}$, Transmission electron microscope images of synapses in the cortex of control (left) and $A b c a 1^{-B /-B}$ (right) mice. A synapse was identified by a well defined postsynaptic density and at least three docked vesicles (arrowheads). $C$, The number of synapses was counted in a total area of $2000 \mu \mathrm{m}^{2}$. Synapses were identified either as excitatory or inhibitory based on morphology (see Materials and Methods). D, The number of perforated synapses, i.e., synapses containing segmented postsynaptic density (arrows). $\boldsymbol{E}$, The numbers of docked vesicles and the vesicles in the reserve pool were counted in 150 excitatory synapses from each mouse. Data show means \pm SEM. ${ }^{*} p<0.05$ and ${ }^{* *} p<0.01$ compared with control mice. $n=5$ per group. Scale bar, $500 \mathrm{~nm}$. 
and LDL (Dehouck et al., 1997) by cultured BCECs were reported. Most ABCA1 is expressed in the basolateral membrane in BCECs rather than the apical membrane whereas most SR-BI is expressed in the apical membrane (Panzenboeck et al., 2006). This orientation of ABCA1 and SR-BI implies the existence of a mechanism for plasma-to-brain cholesterol flux. Interestingly, 24S-OH cholesterol stimulates cholesterol transport across the basolateral membrane of BCECs in vitro (Panzenboeck et al., 2002, 2006) and the CSF-facing membrane of the choroid plexus epithelial cells constituting the blood-CSF barrier (Fujiyoshi et al., 2007). Hence, barriers of the CNS contain a mechanism for mediating a potential increase in cholesterol uptake.

Loss of brain ABCA1 is associated with increased $24 \mathrm{~S}-\mathrm{OH}$ cholesterol production and increased brain selective uptake of radioisotope-labeled esterified cholesterol from plasma HDL. No increase in CE uptake was found in other organs and lower plasma levels of labeled CE correlated with its higher levels in the brain, suggesting that increased brain CE uptake is the primary mechanism underlying the reduced plasma HDL cholesterol levels. Although CE selective uptake rate in the whole brain was increased by two-fold in $A b c a 1^{-B /-B}$ mice, it was still considerably lower than in the liver or adrenals. $\sim 80 \%$ of brain cholesterol in the mouse is in myelin and is subject to slow turnover rates (Dietschy and Turley, 2004). In fact, as little as $2 \%$ of total brain cholesterol may be present in metabolically active neurons where turnover is high (Dietschy and Turley, 2004). Hence, although the relative uptake rate of $\mathrm{CE}$ in whole brain is low, a two-fold increase in uptake in $A b c a 1^{-B /-B}$ mice could significantly impact the cholesterol pool and metabolism in neurons.

SR-BI levels are increased in brain capillaries from $A b c a 1^{-B /-B}$ mice, suggesting that upregulation of SR-BI at the blood-brain barrier mediates the increased brain CE uptake. Although SR-BI knock-out mice do not exhibit changes in brain cholesterol levels or synthesis rate (Quan et al., 2003), reduced brain selective CE uptake was observed in mice lacking SR-BI (Brundert et al., 2005). Elevated brain sitosterol levels support the finding of increased brain sterol uptake. HDL sitosterol is esterified by lecithin:cholesterol acyltransferase almost as efficiently as cholesterol (Temel et al., 2003), suggesting that, once esterified, it may be taken up from HDL in a manner similar to that of CE.

After uptake by BCECs, CE is presumably hydrolyzed to remove the ester bond to allow the efficient transport of free cholesterol to an apolipoprotein acceptor. We observed a marked increase in ApoA-I levels in brain tissue and CSF of $A b c a 1^{-B /-B}$ mice. Lipid-free ApoA-I is lipidated exclusively by ABCA1 (Oram and Heinecke, 2005). Therefore, in the absence of ABCA1 in brain parenchyma, ApoA-I is most likely lipidated by ABCA1 in the BCECs. We propose that levels of ApoA-I are elevated to facilitate the increase in cholesterol transport from plasma into the brain.

The reason underlying the need for increased brain cholesterol uptake in $A b c a 1^{-B /-B}$ mice may be a deficit in cholesterol transport between glial cells and neurons. Glia-derived cholesterol carried by ApoE plays a critical role in synaptic activity (Mauch et al., 2001). Because ABCA1 mediates cholesterol transport from glia to apoE (Hirsch-Reinshagen et al., 2004; Wahrle et al., 2004), a reduction in brain ABCA1 activity may limit the neuronal cholesterol supply from glia. In fact, the absence of ABCA1 inhibits cholesterol efflux from cultured glial cells leading to lipid accumulation (Hirsch-Reinshagen et al., 2004).

Another way to deal with neuronal cholesterol deficit could be to increase synthesis as observed in $A b c a 1^{-B /-B}$ mice. Elevated production of $24 \mathrm{~S}-\mathrm{OH}$ cholesterol could reflect increased choles- terol turnover in glia such as astrocytes. Although CYP46A1 is expressed predominantly in neurons (Lund et al., 1999), glial CYP46A1 expression was reported in AD patients (Brown, III et al., 2004). CYP46A1 is expressed in GFAP-positive cells of control and $A b c a 1^{-B /-B}$ mice. Hence, astrocytes may express small levels of CYP46A1 that could be activated in response to cholesterol accumulation.

Brain cholesterol uptake is not affected by fluctuations in plasma cholesterol levels (Quan et al., 2003; Dietschy and Turley, 2004). Increased cholesterol uptake in $A b c a 1^{-B /-B}$ mice implies a mechanism for altered plasma to brain HDL cholesterol transport regulated specifically by the CNS. Hence, if brain cholesterol balance is perturbed as seen in $A b c a 1^{-B /-B}$ mice, the CNS may initiate a sequence of events to increase cholesterol transport across the BCECs in an attempt to compensate for neuronal cholesterol deficits.

Cholesterol impacts synaptic activity, vesicle release (Mauch et al., 2001) and neurotransmitter receptor and transporter function (Butchbach et al., 2004; Magnani et al., 2004; Ponce et al., 2008). Cholesterol is implicated in the regulation of motor and cognitive function because of its role in myelination (Saher et al., 2005) and isoprenoid synthesis (Kotti et al., 2006). Brain ABCA1 may affect behavioral function via its regulation of brain cholesterol transport and metabolism. Behavioral and synaptic abnormalities observed in $A b c a 1^{-B /-B}$ mice suggest that ABCA1 activity is important for normal neuronal function. Reduced PPI is seen in neuropsychiatric and neurological disorders including schizophrenia, Huntington disease and Tourette's syndrome (Castellanos et al., 1996; Geyer et al., 2002). Antipsychotic drugs reduce locomotor activity and increase PPI in mouse models of schizophrenia (Ralph et al., 2001; Maehara et al., 2008). Reduced activity and increased PPI in $A b c a 1^{-B /-B}$ mice implicate a specific role for brain $A B C A 1$ in sensorimotor gating and suggest that ABCA1 may affect behaviors associated with neuropsychiatric disorders.

The attenuation in the number of cortical synapses and synaptic vesicles in $A b c a 1^{-B /-B}$ mice supports the hypothesis that loss of brain ABCA1 likely leads to a deficit in cholesterol trafficking from glia to neurons which may affect synaptogenesis (Barres and Smith, 2001). The reduction in perforated synapses suggests that ABCA1 is involved in the regulation of synaptic plasticity in the cortex. ABCA1 activity may also impact neuronal membrane lipid composition which could have presynaptic and postsynaptic effects on neurotransmitter release and signaling. Moreover, ApoE receptors are involved in neuronal signaling and synaptic plasticity (Herz and Chen, 2006) and attenuated brain ApoE levels may contribute to functional deficits in $A b c a 1^{-B /-B}$ mice.

Our findings raise the important question of whether cholesterol transport across the blood-brain barrier is altered in neurodegenerative diseases. ABCA1 gene polymorphisms, including loss-of-function mutations, have been associated with an increased risk for Alzheimer's disease (AD) (Chu et al., 2007; Rodríguez-Rodríguez et al., 2007). Reduced plasma HDL levels are reported in AD (Merched et al., 2000) and patients with memory decline (Singh-Manoux et al., 2008). Interestingly, elevated $24 \mathrm{~S}-\mathrm{OH}$ cholesterol levels in plasma and CSF (Lütjohann et al., 2000; Papassotiropoulos et al., 2002; Schönknecht et al., 2002) have also been observed in $\mathrm{AD}$. These data, in addition to the reports suggesting that overexpression of ABCA1 in the brain decreases amyloid deposition (Wahrle et al., 2008) and improves neuronal function (Jiang et al., 2008), all point to significant disturbances in CNS cholesterol homeostasis that may be influenced at least in part by ABCA1 function. Together, these data 
encourage further evaluation of brain ABCA1 as a therapeutic target in neurodegenerative disease.

\section{References}

Acton S, Rigotti A, Landschulz KT, Xu S, Hobbs HH, Krieger M (1996) Identification of scavenger receptor SR-BI as a high density lipoprotein receptor. Science 271:518-520.

Barres BA, Smith SJ (2001) Neurobiology. Cholesterol—making or breaking the synapse. Science 294:1296-1297.

Berge KE (2003) Sitosterolemia: a gateway to new knowledge about cholesterol metabolism. Ann Med 35:502-511.

Björkhem I, Meaney S (2004) Brain cholesterol: long secret life behind a barrier. Arterioscler Thromb Vasc Biol 24:806-815.

Bowman GL, Kaye JA, Moore M, Waichunas D, Carlson NE, Quinn JF (2007) Blood-brain barrier impairment in Alzheimer disease: stability and functional significance. Neurology 68:1809-1814.

Brooks-Wilson A, Marcil M, Clee SM, Zhang LH, Roomp K, van Dam M, Yu L, Brewer C, Collins JA, Molhuizen HO, Loubser O, Ouelette BF, Fichter K, Ashbourne-Excoffon KJ, Sensen CW, Scherer S, Mott S, Denis M, Martindale D, Frohlich J, et al. (1999) Mutations in ABC1 in Tangier disease and familial high-density lipoprotein deficiency. Nat Genet 22:336-345.

Brown J 3rd, Theisler C, Silberman S, Magnuson D, Gottardi-Littell N, Lee JM, Yager D, Crowley J, Sambamurti K, Rahman MM, Reiss AB, Eckman CB, Wolozin B (2004) Differential expression of cholesterol hydroxylases in Alzheimer's disease. J Biol Chem 279:34674-34681.

Brundert M, Ewert A, Heeren J, Behrendt B, Ramakrishnan R, Greten H, Merkel M, Rinninger F (2005) Scavenger receptor class B type I mediates the selective uptake of high-density lipoprotein-associated cholesteryl ester by the liver in mice. Arterioscler Thromb Vasc Biol 25:143-148.

Brunham LR, Kruit JK, Iqbal J, Fievet C, Timmins JM, Pape TD, Coburn BA, Bissada N, Staels B, Groen AK, Hussain MM, Parks JS, Kuipers F, Hayden MR (2006) Intestinal ABCA1 directly contributes to HDL biogenesis in vivo. J Clin Invest 116:1052-1062.

Brunham LR, Kruit JK, Pape TD, Timmins JM, Reuwer AQ, Vasanji Z, Marsh BJ, Rodrigues B, Johnson JD, Parks JS, Verchere CB, Hayden MR (2007) Beta-cell ABCA1 influences insulin secretion, glucose homeostasis and response to thiazolidinedione treatment. Nat Med 13:340-347.

Butchbach ME, Tian G, Guo H, Lin CL (2004) Association of excitatory amino acid transporters, especially EAAT2, with cholesterol-rich lipid raft microdomains: importance for excitatory amino acid transporter localization and function. J Biol Chem 279:34388-34396.

Carlin RK, Siekevitz P (1983) Plasticity in the central nervous system: do synapses divide? Proc Natl Acad Sci U S A 80:3517-3521.

Castellanos FX, Fine EJ, Kaysen D, Marsh WL, Rapoport JL, Hallett M (1996) Sensorimotor gating in boys with Tourette's syndrome and ADHD: preliminary results. Biol Psychiatry 39:33-41.

Chu LW, Li Y, Li Z, Tang AY, Cheung BM, Leung RY, Yik PY, Jin DY, Song YQ (2007) A novel intronic polymorphism of ABCA1 gene reveals risk for sporadic Alzheimer's disease in Chinese. Am J Med Genet B Neuropsychiatr Genet 144B:1007-1013.

Dehouck B, Fenart L, Dehouck MP, Pierce A, Torpier G, Cecchelli R (1997) A new function for the LDL receptor: transcytosis of LDL across the blood-brain barrier. J Cell Biol 138:877-889.

DeMattos RB, Bales KR, Parsadanian M, O'Dell MA, Foss EM, Paul SM, Holtzman DM (2002) Plaque-associated disruption of CSF and plasma amyloid-beta (Abeta) equilibrium in a mouse model of Alzheimer's disease. J Neurochem 81:229-236.

Dietschy JM, Turley SD (2004) Thematic review series: brain Lipids. Cholesterol metabolism in the central nervous system during early development and in the mature animal. J Lipid Res 45:1375-1397.

Elshourbagy NA, Boguski MS, Liao WS, Jefferson LS, Gordon JI, Taylor JM (1985) Expression of rat apolipoprotein A-IV and A-I genes: mRNA induction during development and in response to glucocorticoids and insulin. Proc Natl Acad Sci U S A 82:8242-8246.

Fujiyoshi M, Ohtsuki S, Hori S, Tachikawa M, Terasaki T (2007) 24Shydroxycholesterol induces cholesterol release from choroid plexus epithelial cells in an apical- and apoE isoform-dependent manner concomitantly with the induction of ABCA1 and ABCG1 expression. J Neurochem 100:968-978.
Geyer MA, McIlwain KL, Paylor R (2002) Mouse genetic models for prepulse inhibition: an early review. Mol Psychiatry 7:1039-1053.

Glass C, Pittman RC, Weinstein DB, Steinberg D (1983a) Dissociation of tissue uptake of cholesterol ester from that of apoprotein A-I of rat plasma high density lipoprotein: selective delivery of cholesterol ester to liver, adrenal, and gonad. Proc Natl Acad Sci U S A 80:5435-5439.

Glass CK, Pittman RC, Keller GA, Steinberg D (1983b) Tissue sites of degradation of apoprotein A-I in the rat. J Biol Chem 258:7161-7167.

Gleiberman AS, Encinas JM, Mignone JL, Michurina T, Rosenfeld MG, Enikolopov G (2005) Expression of nestin-green fluorescent protein transgene marks oval cells in the adult liver. Dev Dyn 234:413-421.

Goritz C, Mauch DH, Pfrieger FW (2005) Multiple mechanisms mediate cholesterol-induced synaptogenesis in a CNS neuron. Mol Cell Neurosci 29:190-201.

Goti D, Hrzenjak A, Levak-Frank S, Frank S, van der Westhuyzen DR, Malle E, Sattler W (2001) Scavenger receptor class B, type I is expressed in porcine brain capillary endothelial cells and contributes to selective uptake of HDL-associated vitamin E. J Neurochem 76:498-508.

Herz J, Chen Y (2006) Reelin, lipoprotein receptors and synaptic plasticity. Nat Rev Neurosci 7:850-859.

Hirsch-Reinshagen V, Zhou S, Burgess BL, Bernier L, McIsaac SA, Chan JY, Tansley GH, Cohn JS, Hayden MR, Wellington CL (2004) Deficiency of ABCA1 impairs apolipoprotein E metabolism in brain. J Biol Chem 279:41197-41207.

Jansen PJ, Lütjohann D, Abildayeva K, Vanmierlo T, Plösch T, Plat J, von Bergmann K, Groen AK, Ramaekers FC, Kuipers F, Mulder M (2006) Dietary plant sterols accumulate in the brain. Biochim Biophys Acta 1761:445-453.

Jiang Q, Lee CY, Mandrekar S, Wilkinson B, Cramer P, Zelcer N, Mann K, Lamb B, Willson TM, Collins JL, Richardson JC, Smith JD, Comery TA, Riddell D, Holtzman DM, Tontonoz P, Landreth GE (2008) ApoE promotes the proteolytic degradation of Abeta. Neuron 58:681-693.

Kotti TJ, Ramirez DM, Pfeiffer BE, Huber KM, Russell DW (2006) Brain cholesterol turnover required for geranylgeraniol production and learning in mice. Proc Natl Acad Sci U S A 103:3869-3874.

Lindenthal B, Sudhop T, Schiedermaier P, Agnan M, Sauerbruch T, von Bergmann K (2002) Serum plant sterols and biliary cholesterol secretion in humans: studies with ursodeoxycholic acid. J Lipid Res 43:1072-1077.

Lund EG, Guileyardo JM, Russell DW (1999) cDNA cloning of cholesterol 24-hydroxylase, a mediator of cholesterol homeostasis in the brain. Proc Natl Acad Sci U S A 96:7238-7243.

Lund EG, Xie C, Kotti T, Turley SD, Dietschy JM, Russell DW (2003) Knockout of the cholesterol 24-hydroxylase gene in mice reveals a brainspecific mechanism of cholesterol turnover. J Biol Chem 278:22980-22988.

Lütjohann D, Papassotiropoulos A, Björkhem I, Locatelli S, Bagli M, Oehring RD, Schlegel U, Jessen F, Rao ML, von Bergmann K, Heun R (2000) Plasma 24S-hydroxycholesterol (cerebrosterol) is increased in Alzheimer and vascular demented patients. J Lipid Res 41:195-198.

Lütjohann D, Brzezinka A, Barth E, Abramowski D, Staufenbiel M, von Bergmann K, Beyreuther K, Multhaup G, Bayer TA (2002) Profile of cholesterol-related sterols in aged amyloid precursor protein transgenic mouse brain. J Lipid Res 43:1078-1085.

Maehara S, Hikichi H, Satow A, Okuda S, Ohta H (2008) Antipsychotic property of a muscarinic receptor agonist in animal models for schizophrenia. Pharmacol Biochem Behav 91:140-149.

Magnani F, Tate CG, Wynne S, Williams C, Haase J (2004) Partitioning of the serotonin transporter into lipid microdomains modulates transport of serotonin. J Biol Chem 279:38770-38778.

Mauch DH, Nägler K, Schumacher S, Göritz C, Müller EC, Otto A, Pfrieger FW (2001) CNS synaptogenesis promoted by glia-derived cholesterol. Science 294:1354-1357.

Merched A, Xia Y, Visvikis S, Serot JM, Siest G (2000) Decreased highdensity lipoprotein cholesterol and serum apolipoprotein AI concentrations are highly correlated with the severity of Alzheimer's disease. Neurobiol Aging 21:27-30.

Oram JF, Heinecke JW (2005) ATP-binding cassette transporter A1: a cell cholesterol exporter that protects against cardiovascular disease. Physiol Rev 85:1343-1372.

Panzenboeck U, Balazs Z, Sovic A, Hrzenjak A, Levak-Frank S, Wintersperger A, Malle E, Sattler W (2002) ABCA1 and scavenger receptor class B, type $\mathrm{I}$, are modulators of reverse sterol transport at an in vitro blood-brain 
barrier constituted of porcine brain capillary endothelial cells. J Biol Chem 277:42781-42789.

Panzenboeck U, Kratzer I, Sovic A, Wintersperger A, Bernhart E, Hammer A, Malle E, Sattler W (2006) Regulatory effects of synthetic liver X receptor- and peroxisome-proliferator activated receptor agonists on sterol transport pathways in polarized cerebrovascular endothelial cells. Int J Biochem Cell Biol 38:1314-1329.

Papassotiropoulos A, Lütjohann D, Bagli M, Locatelli S, Jessen F, Buschfort R, Ptok U, Björkhem I, von Bergmann K, Heun R (2002) 24Shydroxycholesterol in cerebrospinal fluid is elevated in early stages of dementia. J Psychiatr Res 36:27-32.

Pitas RE, Boyles JK, Lee SH, Hui D, Weisgraber KH (1987) Lipoproteins and their receptors in the central nervous system. Characterization of the lipoproteins in cerebrospinal fluid and identification of apolipoprotein B,E(LDL) receptors in the brain. J Biol Chem 262:14352-14360.

Pittman RC, Taylor CA Jr (1986) Methods for assessment of tissue sites of lipoprotein degradation. Methods Enzymol 129:612-628.

Pittman RC, Carew TE, Glass CK, Green SR, Taylor CA Jr, Attie AD (1983) A radioiodinated, intracellularly trapped ligand for determining the sites of plasma protein degradation in vivo. Biochem J 212:791-800.

Pittman RC, Knecht TP, Rosenbaum MS, Taylor CA Jr (1987) A nonendocytotic mechanism for the selective uptake of high density lipoproteinassociated cholesterol esters. J Biol Chem 262:2443-2450.

Ponce J, de la Ossa NP, Hurtado O, Millan M, Arenillas JF, Dávalos A, Gasull $\mathrm{T}$ (2008) Simvastatin reduces the association of NMDA receptors to lipid rafts: a cholesterol-mediated effect in neuroprotection. Stroke 39:1269-1275.

Quan G, Xie C, Dietschy JM, Turley SD (2003) Ontogenesis and regulation of cholesterol metabolism in the central nervous system of the mouse. Brain Res Dev Brain Res 146:87-98.

Ralph RJ, Paulus MP, Fumagalli F, Caron MG, Geyer MA (2001) Prepulse inhibition deficits and perseverative motor patterns in dopamine transporter knock-out mice: differential effects of D1 and D2 receptor antagonists. J Neurosci 21:305-313.

Rodríguez-Rodríguez E, Mateo I, Llorca J, Sánchez-Quintana C, Infante J, Garca-Gorostiaga I, Sánchez-Juan P, Berciano J, Combarros O (2007) Association of genetic variants of ABCA1 with Alzheimer's disease risk. Am J Med Genet B Neuropsychiatr Genet 144B:964-968.

Saher G, Brügger B, Lappe-Siefke C, Möbius W, Tozawa R, Wehr MC, Wieland F, Ishibashi S, Nave KA (2005) High cholesterol level is essential for myelin membrane growth. Nat Neurosci 8:468-475.

Schönknecht P, Lütjohann D, Pantel J, Bardenheuer H, Hartmann T, von Bergmann K, Beyreuther K, Schröder J (2002) Cerebrospinal fluid 24Shydroxycholesterol is increased in patients with Alzheimer's disease compared to healthy controls. Neurosci Lett 324:83-85.

Singh-Manoux A, Gimeno D, Kivimaki M, Brunner E, Marmot MG (2008) Low HDL cholesterol is a risk factor for deficit and decline in memory in midlife: the Whitehall II study. Arterioscler Thromb Vasc Biol 28:1556-1562.
Tachikawa M, Watanabe M, Hori S, Fukaya M, Ohtsuki S, Asashima T, Terasaki T (2005) Distinct spatio-temporal expression of ABCA and ABCG transporters in the developing and adult mouse brain. J Neurochem 95:294-304.

Temel RE, Gebre AK, Parks JS, Rudel LL (2003) Compared with Acyl-CoA: cholesterol O-acyltransferase (ACAT) 1 and lecithin:cholesterol acyltransferase, ACAT2 displays the greatest capacity to differentiate cholesterol from sitosterol. J Biol Chem 278:47594-47601.

Timmins JM, Lee JY, Boudyguina E, Kluckman KD, Brunham LR, Mulya A, Gebre AK, Coutinho JM, Colvin PL, Smith TL, Hayden MR, Maeda N, Parks JS (2005) Targeted inactivation of hepatic Abcal causes profound hypoalphalipoproteinemia and kidney hypercatabolism of apoA-I. J Clin Invest 115:1333-1342.

Triguero D, Buciak J, Pardridge WM (1990) Capillary depletion method for quantification of blood-brain barrier transport of circulating peptides and plasma proteins. J Neurochem 54:1882-1888.

Tronche F, Kellendonk C, Kretz O, Gass P, Anlag K, Orban PC, Bock R, Klein R, Schütz G (1999) Disruption of the glucocorticoid receptor gene in the nervous system results in reduced anxiety. Nat Genet 23:99-103.

Valenza M, Rigamonti D, Goffredo D, Zuccato C, Fenu S, Jamot L, Strand A Tarditi A, Woodman B, Racchi M, Mariotti C, Di Donato S, Corsini A, Bates G, Pruss R, Olson JM, Sipione S, Tartari M, Cattaneo E (2005) Dysfunction of the cholesterol biosynthetic pathway in Huntington's disease. J Neurosci 25:9932-9939.

Vance JE, Hayashi H, Karten B (2005) Cholesterol homeostasis in neurons and glial cells. Semin Cell Dev Biol 16:193-212.

Wahrle SE, Jiang H, Parsadanian M, Legleiter J, Han X, Fryer JD, Kowalewski T, Holtzman DM (2004) ABCA1 is required for normal central nervous system ApoE levels and for lipidation of astrocyte-secreted apoE. J Biol Chem 279:40987-40993.

Wahrle SE, Jiang H, Parsadanian M, Kim J, Li A, Knoten A, Jain S, HirschReinshagen V, Wellington CL, Bales KR, Paul SM, Holtzman DM (2008) Overexpression of ABCA1 reduces amyloid deposition in the PDAPP mouse model of Alzheimer disease. J Clin Invest 118:671-682.

Waterham HR, Koster J, Romeijn GJ, Hennekam RC, Vreken P, Andersson HC, FitzPatrick DR, Kelley RI, Wanders RJ (2001) Mutations in the 3beta-hydroxysterol Delta24-reductase gene cause desmosterolosis, an autosomal recessive disorder of cholesterol biosynthesis. Am J Hum Genet 69:685-694.

Weiler-Güttler H, Sommerfeldt M, Papandrikopoulou A, Mischek U, Bonitz D, Frey A, Grupe M, Scheerer J, Gassen HG (1990) Synthesis of apolipoprotein A-1 in pig brain microvascular endothelial cells. J Neurochem 54:444-450.

Wellington CL, Walker EK, Suarez A, Kwok A, Bissada N, Singaraja R, Yang YZ, Zhang LH, James E, Wilson JE, Francone O, McManus BM, Hayden MR (2002) ABCA1 mRNA and protein distribution patterns predict multiple different roles and levels of regulation. Lab Invest 82:273-283. 